\title{
Impact of burn severity on soil properties in a Pinus pinaster ecosystem immediately after fire
}

\author{
Víctor Fernández-García (D) A,C, Elena Marcos A , José Manuel \\ Fernández-Guisuraga ${ }^{\mathrm{A}}$, Angela Taboada ${ }^{\mathrm{A}, \mathrm{B}}$, Susana Suárez-Seoane ${ }^{\mathrm{A}}$ and \\ Leonor Calvo ${ }^{\mathrm{A}}$ \\ A Ecology, Department of Biodiversity and Environmental Management, Faculty of Biological and \\ Environmental Sciences, Universidad de León, 24071 León, Spain. \\ ${ }^{B}$ Institute of Environmental Research, Universidad de Léon, 24071 León, Spain. \\ ${ }^{\mathrm{C}}$ Corresponding author. Email: vferg@unileon.es
}

\begin{abstract}
We analyse the effects of burn severity on individual soil properties and soil quotients in Mediterranean fireprone pine forests immediately after a wildfire. Burn severity was measured in the field through the substrate stratum of the Composite Burn Index and soil samples were taken 7-9 days after a wildfire occurred in a Pinus pinaster Ait. ecosystem. In each soil sample, we analysed physical (size of soil aggregates), chemical ( $\mathrm{pH}$, organic $\mathrm{C}$, total $\mathrm{N}$ and available $\mathrm{P}$ ) and biological (microbial biomass $\mathrm{C}, \beta$-glucosidase, urease and acid phosphatase activities) properties. Size of aggregates decreased in the areas affected by high burn severity. Additionally, moderate and high severities were associated with increases in $\mathrm{pH}$ and available $\mathrm{P}$ concentration and with decreases in organic $\mathrm{C}$ concentration. Microbial biomass $\mathrm{C}$ showed similar patterns to organic $\mathrm{C}$ along the burn severity gradient. The enzymatic activities of phosphatase and $\beta$-glucosidase showed the highest sensitivity to burn severity, as they strongly decreased from the low-severity scenarios. Among the studied soil quotients, the $\mathrm{C}: \mathrm{N}$ ratio, microbial quotient and $\beta$-glucosidase : microbial biomass $\mathrm{C}$ quotient decreased with burn severity. This work provides valuable information on the impact of burn severity on the functioning of sandy siliceous soils in fire-prone pine ecosystems.
\end{abstract}

Additional keywords: biological properties, chemical properties, maritime pine, physical properties, wildfire.

Received 10 July 2018, accepted 21 December 2018, published online xx xxxxx xxxx

\section{Introduction}

Wildfires are a determining factor in the functioning and structure of fire-prone forests (Keeley et al. 2012). In general, these forests are adapted to natural fire regimes, recovering under a wide range of fire frequencies and severities (Noss et al. 2006). However, burn severity is increasing in many parts of the world because of changes in land-use and climatic conditions (Lindner et al. 2008; Moreira et al. 2011; Doblas-Miranda et al. 2017). This is the case in the Mediterranean Basin, where there is

10 major concern about the ecological consequences of highseverity fires on soils in fire-prone pine ecosystems (Pausas et al. 2008), which are the forests most affected by fire in this region (Moreira et al. 2012).

Burn severity is used to describe the loss of or change in 15 biomass caused by fire in the ecosystem (Key and Benson 2006; Keeley 2009; Fernández-García et al. 2018a). The most common approach for estimating burn severity in forest soils is through visual evidence of the loss of litter and changes in soil upper layers, such as alterations in soil colour and structure, soil

20 char or ash depth (Parsons et al. 2010). This evidence is highly valuable for managers because it is related to other physical, chemical and biological changes in soils (Vega et al. 2013) and to some extent to ecosystem responses after fire, such as soil erosion (Shakesby 2011; Vieira et al. 2015) or vegetation recovery (Fernández-García et al. 2018b). However, other factors such as vegetation and soil type mediate changes caused by fire in ecosystems as well as potential responses after fire, thus limiting the predictive capacity of burn severity measurements (Keeley 2009). It is therefore necessary to study the relationships between burn severity and changes in soil status and processes in different types of ecosystems and especially in those prone to fire. A better understanding of the impact of burn severity on ecosystems may help to clarify its value as a tool to identify target areas in which to implement emergency stabilisation strategies (Merino et al. 2018). Some studies have analysed changes in soils related to burn severity (Jordán et al. 2011; Jain et al. 2012; Pingree et al. 2012; Dzwonko et al. 2015; Miesel et al. 2015; Moody et al. 2016), but few analyse the effects of burn severity on soil properties immediately after a wildfire (Vega et al. 2013).

Several physical, chemical and biological soil properties provide relevant information on soil status and functioning in relation to fire (Certini 2005). Among physical properties that have shown to be affected by fire are those related to soil 
structure (e.g. aggregate size) (Jordán et al. 2011; Mataix-Solera et al. 2011). Changes in soil structure can play an important role in hydrological, biological and gas-exchange processes (Neary et al. 1999; Puglisi et al. 2006). Soil structure also provides information on soil resistance to external factors, and could thus be indicative of soil vulnerability to erosion (Cerdá and Jordan 2010). Additionally, several soil chemical properties such as $\mathrm{pH}$ and nutrient-supplying capacity (carbon $(\mathrm{C})$, nitrogen $(\mathrm{N})$ and phosphorus (P)) are usually affected by fire (Certini 2005).

10 These soil properties show a close relationship with ecosystem productivity (Arshad and Martin 2002), as well as plant and microbial diversity (Roem and Berendse 2000). Nevertheless, biological properties tend to be affected by lower-intensity disturbances than chemical parameters (Paz-Ferreiro and $\mathrm{Fu}$

15 2016; Alcañiz et al. 2018). Fire-induced changes in microbial biomass also involve impacts on nutrient cycling and soil detoxification capacity as microorganisms are both a source and a sink of nutrients, and they participate in the degradation of xenobiotics and in the immobilisation of heavy metals

20 (Gil-Sotres et al. 2005; Lagomarsino et al. 2009). Likewise, the microbial biomass, with plant and animal residues are the main sources of soil enzymes, responsible for the catalysis of soil biochemical reactions (Tabatabai 1994; Li et al. 2009). As proteins, soil enzymes are denatured by fairly low temperatures

$25\left(60-70^{\circ} \mathrm{C}\right)($ Tabatabai 1994), and can therefore be significantly affected immediately after a fire, depending on burn severity (Vega et al. 2013). Among soil enzymes, those involved in C, N and $\mathrm{P}$ cycles are considered especially relevant in ecosystem functioning, because they allow soil biota to obtain the major 30 nutrients from complex organic substrates (Lagomarsino et al. 2009; Li et al. 2009; Adetunji et al. 2017).

According to Bastida et al. (2008) and Lagomarsino et al. (2009), the study of changes in soil quotients (ratios between two different soil properties) can provide additional information

35 on impacts on soil status and functioning. Fire impacts on soil quotients may be more consistent among different soils because they are relativised. One of the most used soil quotients is the $\mathrm{C}: \mathrm{N}$ ratio (Badía et al. 2014; Schnecker et al. 2015), which controls organic matter mineralisation and the development of

40 microorganisms (Wild 1992). This quotient, which is sensitive to fire (Vega et al. 2013), shows low variability in undisturbed forest soils (Wild 1992), and in therefore likely to be highly generalisable. Another soil quotient commonly analysed after disturbances is the microbial quotient $\left(\mathrm{Q}_{\mathrm{mic}}\right)$, a ratio of microbial

45 biomass $\mathrm{C}$ and soil organic $\mathrm{C}$. This quotient may be more informative about changes in organic matter than the single assessment of soil organic $\mathrm{C}$ and microbial biomass $\mathrm{C}$ separately (Piao et al. 2001). Thus, $Q_{\text {mic }}$ provides an idea of substrate availability for microorganisms (Lagomarsino et al. 2009; Paz-

50 Ferreiro and $\mathrm{Fu} 2016$ ) and organic matter stabilisation (Piao et al. 2001). Additionally, specific activities of soil enzymes (enzyme activity per unit of microbial biomass C) have been proposed as indicators of the physiological capacity of the microbial community (Waldrop et al. 2000; Bastida et al. 5 2008; Lagomarsino et al. 2009).

The objective of the present study is to analyse the effects of field-estimated burn severity on individual soil properties, as well on as soil quotients indicative of soil status and processes in a Pinus pinaster forest immediately after fire. Specifically, we aim to analyse the effects of burn severity on (i) physical (mean weight diameter), chemical ( $\mathrm{pH}$, organic $\mathrm{C}$, total $\mathrm{N}$, available $\mathrm{P}$ ) and biological (microbial biomass $\mathrm{C}, \beta$-glucosidase, urease and acid phosphatase activities) soil properties, as well as on (ii) soil quotients $\left(C: N, Q_{\text {mic }}\right.$ and the activity of $\beta$-glucosidase urease and acid phosphatase per microbial biomass $\mathrm{C}$ unit), incorporating the study of the specific activity of soil enzymes into the fire ecology discipline. According to prior studies focused on the effects of fire on soils, we hypothesised that physical (Jordán et al. 2011; Mataix-Solera et al. 2011), chemical (Marcos et al. 2007; Badía et al. 2014) and biological (Neary et al. 2008; Vega et al. 2013) properties and soil quotients (Vega et al. 2013) would be affected at different severities. We expected biological properties to be affected at lower severities than physical and chemical properties (Santín and Doerr 2016). Besides, as soil quotients combine the information of two different soil properties (Bastida et al. 2008; Lagomarsino et al. 2009) we expected them to be more sensitive to burn severity than single soil properties.

\section{Material and Methods}

Study site

The study was conducted within a fire scar that burned on 21 July 2015 in Sierra del Teleno (León Province, north-west Iberian Peninsula) (Fig. 1). This wildfire affected a Pinus pinaster Ait. (maritime pine) ecosystem, which is the type of forest most affected by fire on the Iberian Peninsula (Area de Defensa contra Incendios Forestales del Ministerio de Agricultura, Alimentación y Medio Ambiente 2012; Instituto da Conservação da Natureza e das Florestas 2015).

The wildfire scar is an area of 16 ha located on a south-eastfacing hillside with a slight slope $(5 \%)$ and an average altitude of $1025 \mathrm{~m}$. The soils are characterised by a dark acid surface horizon rich in organic matter, weakly developed subsurface horizons, free-draining conditions and absence of carbonates. These soils are classified as Haplic Umbrisols according to the World Reference Base for Soil Resources (WRB) system (Jones et al. 2005). The soil textural class in the study area is sandy loam. The parent material is silt, clay, sand, boulders and conglomerates from the Neogene period (GEODE 2018). The climate is Mediterranean, Csb type according to Köppen, and classified by the Spanish meteorological survey as temperate with dry temperate summers (Agencia Estatal de Meteorología and Instituto de Meteorologia de Portugal 2011). Mean annual precipitation is $\sim 685 \mathrm{~mm}$ and mean annual temperature is $10^{\circ} \mathrm{C}$ (Ninyerola et al. 2005). The understorey of the P. pinaster forest is dominated by Erica australis L., Halimium lasianthum (Lam.) Spach. and Pterospartum tridentatum (L.) Willk.

\section{Data collection \\ Field sampling}

Field sampling was carried out on the 7th, 8th and 9th day after the wildfire. In the period between the wildfire and field sampling, there was no precipitation in the study area, and the atmospheric conditions were warm (mean temperature of $20.65^{\circ} \mathrm{C}$ ), dry (mean relative humidity of $49.62 \%$ ) and not windy (mean wind speed of $11.75 \mathrm{~km} \mathrm{~h}^{-1}$ ) (National Oceanic and Atmospheric Administration 2018). Additionally, soils were 

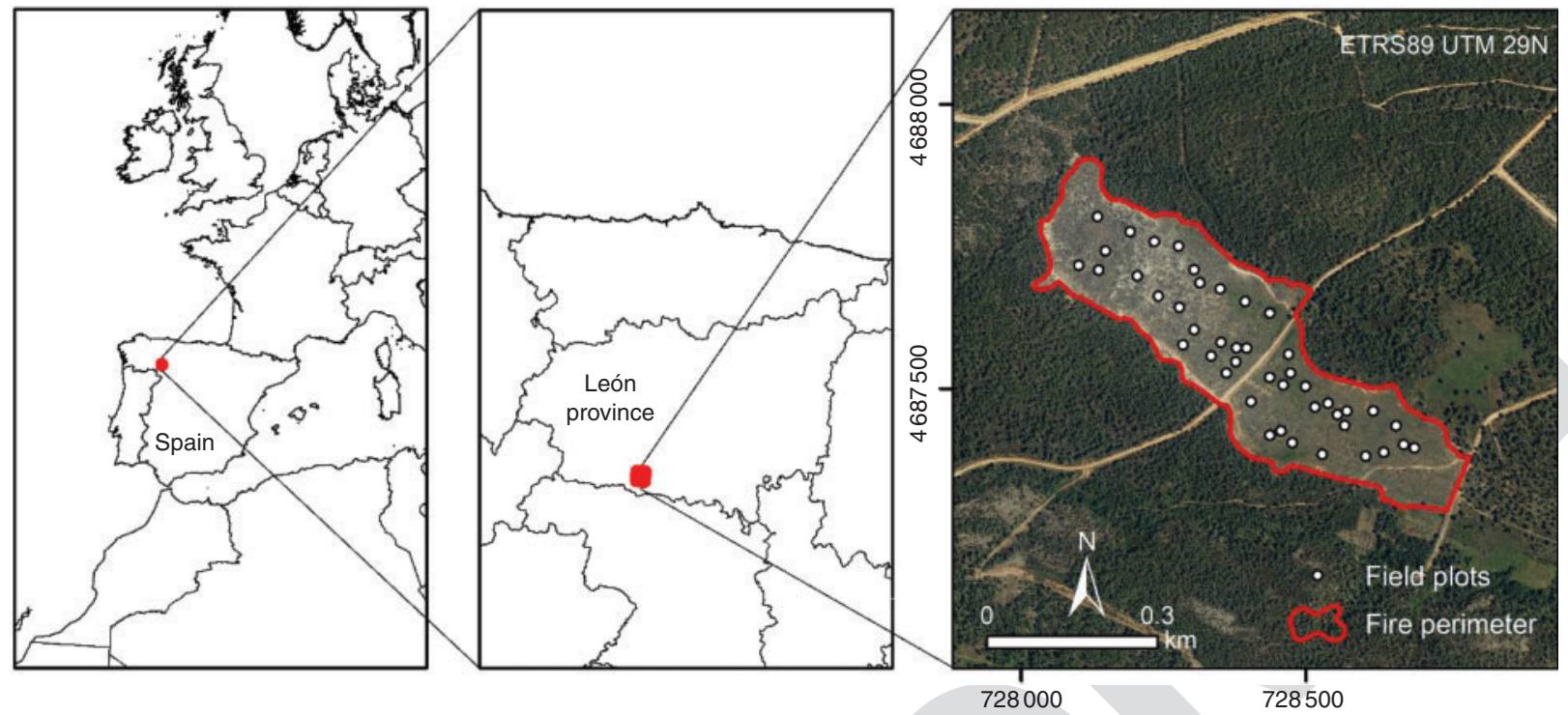

Fig. 1. Location of the study area on the Iberian Peninsula (left), and in León province (centre). The image on the right shows the fire perimeter and the spatial distribution of the field plots in an orthophotography taken in 2017.

Table 1. Factors and scores used as reference to quantify soil burn severity (substrates stratum of the Composite Burn Index) according to Fernández-García et al. (2018a)

Scores shown in the table were assigned to each rating factor, as well as mean values when the situation was considered intermediate (i.e. a value of 0.75 was assigned for litter and light fuel consumed when it was $10 \%$ ). UB, unburned; $n$ indicates the number of plots distributed in each severity category. Note that both UB and low-severity categories correspond to no apparent changes in mineral soil

\begin{tabular}{|c|c|c|c|c|c|c|c|}
\hline \multirow[t]{3}{*}{ Rating factors } & \multicolumn{7}{|c|}{ Burn severity scale } \\
\hline & \multirow{2}{*}{$\begin{array}{l}\mathrm{UB}(n=0) \\
0\end{array}$} & \multicolumn{2}{|c|}{ Low $(n=2)$} & \multicolumn{2}{|c|}{ Moderate $(n=24)$} & \multicolumn{2}{|l|}{ High $(n=18)$} \\
\hline & & 0.5 & 1 & 1.5 & 2 & 2.5 & 3 \\
\hline \multirow{2}{*}{$\begin{array}{l}\text { Litter and light fuel consumed } \\
\text { Char and colour }\end{array}$} & No changes & $0-10 \%$ & $10-20 \%$ & $20-40 \%$ & $40-80 \%$ & $80-98 \%$ & $98 \%$ \\
\hline & No changes & \multicolumn{2}{|c|}{$\begin{array}{l}\text { Blackened litter, no } \\
\text { changes in soil }\end{array}$} & \multicolumn{2}{|c|}{$\begin{array}{l}\text { Charred remains, recog- } \\
\text { nisable litter }\end{array}$} & $\begin{array}{l}\text { Grey and white ash, } \\
\text { grey soil }\end{array}$ & $\begin{array}{l}\text { White ash, reddened } \\
\text { soil }\end{array}$ \\
\hline
\end{tabular}

dry, as there was no precipitation for 34 days prior to field sampling.

We established a total of $44(1 \times 1-\mathrm{m})$ plots randomly distributed within the burned area (Fig. 1). In each plot, we estimated soil burn severity using the substrate stratum of the Composite Burn Index-based protocol (CBI) proposed by Fernández-García et al. (2018a) for $P$. pinaster ecosystems in the Iberian Peninsula (Table 1; Fig. 2). Visual evidence used in this index was: (1) the proportion of litter and light fuel (leaves,

10 needles and woody material less than $2 \mathrm{~cm}$ in diameter located on the ground surface) consumed by fire, and (2) char depth (considering litter and mineral soil), and colour of ash and mineral soil. Char depth and colour of ash and mineral soil were closely linked, and therefore, considered together (see charac15 terisation in Table 1 ).

To analyse the relationships between soil burn severity and soil properties, we collected a soil sample in each field plot. Each sample was composed of four subsamples collected along two perpendicular transects using an auger $(5-\mathrm{cm}$ diameter $\times 3-\mathrm{cm}$ depth), after removing the litter and post-burn residues (ash and scorched debris). The soil samples were air-dried, sieved $(<2 \mathrm{~mm})$ and stored until laboratory analysis $\left(20^{\circ} \mathrm{C}\right)$.

\section{Soil analyses}

From each soil sample, we analysed soil physical (mean weight diameter (MWD)), chemical ( $\mathrm{pH}$, organic $\mathrm{C}$, total $\mathrm{N}$ and available $\mathrm{P}$ ) and biological (microbial biomass $\mathrm{C}, \beta$-glucosidase, urease and acid phosphatase) properties.

Aggregate size distribution was determined by dry-sieving the soil samples through 1-, 0.25-, 0.1- and 0.05-mm sieves for $120 \mathrm{~s}$ in an electromechanical shaker (Kemper and Rosenau 1986). The results were expressed as MWD, which reflects the average size of the stable aggregates (Cerdà and Jordán 2010; Mataix-Solera et al. 2011). MWD was calculated using the following equation (Eqn 1):

$$
\mathrm{MWD}=\sum_{i=1}^{n} \mathrm{X}_{i} \mathrm{~W}_{i}
$$



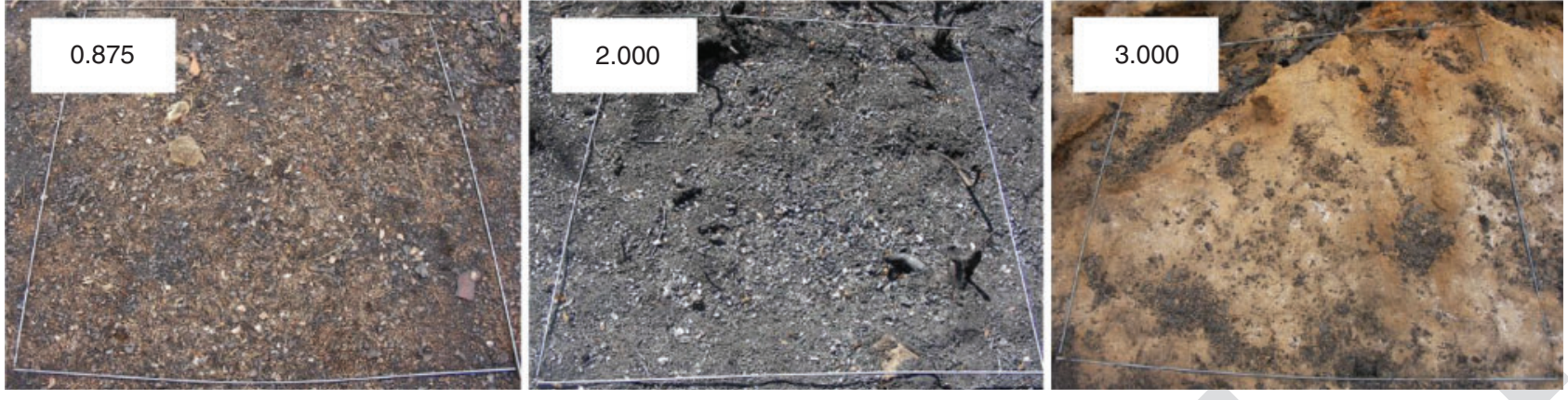

Fig. 2. Examples of plots with different soil burn severity values in Composite Burn Index $(\mathrm{CBI})$ units. The panel on the left $(\mathrm{CBI}=0.875)$ shows a field plot burned at low severity ( $10 \%$ of litter and light fuel was consumed and litter blackened with, in general, no changes in mineral soil). The panel in the middle $(\mathrm{CBI}=2)$ shows a field plot burned at moderate severity $(60 \%$ of the litter and light fuel was consumed and there were charred remains with recognisable litter in some areas). The panel on the right $(\mathrm{CBI}=3)$ shows soil burned at high severity $(98 \%$ of litter and light fuel was consumed, all ash was white and the soil was completely reddened). See Table 1 for further information.

where $\mathrm{X}$ is the mean particle size in millimetres, and $\mathrm{W}$ the percentage weight of each soil fraction.

Soil $\mathrm{pH}$ was determined at $25^{\circ} \mathrm{C}$ in a suspension of soil: deionised water $(1: 2.5 \mathrm{w} / \mathrm{v})$. To analyse the soil organic $\mathrm{C}$, we ground the soils to $<0.15-\mathrm{mm}$ particle size using a pestle and mortar, and we applied Walkley-Black dichromate digestion (Nelson and Sommers 1982). As the soil in the study site is noncalcareous, values obtained for soil organic $\mathrm{C}$ and total $\mathrm{C}$ are

10 very similar (Nelson and Sommers 1982; Vega et al. 2013). Total $\mathrm{N}$ (sum of organic $\mathrm{N}, \mathrm{NO}_{3}{ }^{-}, \mathrm{NO}_{2}{ }^{-}$and $\mathrm{NH}_{4}{ }^{+}$) was determined by the Kjeldahl method (Bremner and Mulvaney 1982) using a DK 20 digestion unit (VELP Scientifica). Available $\mathrm{P}$ was analysed following the procedure of Olsen et al.

15 (1954), at 882-nm wavelength on an UV Mini 1240 spectrophotometer (Shimadzu Corporation)

We analysed microbial biomass $\mathrm{C}(\mathrm{MBC})$ by the fumigationextraction method (Vance et al. 1987). This procedure uses the difference $\left(\mathrm{E}_{\mathrm{C}}\right)$ in organic $\mathrm{C}$ (analysed by Walkley-Black 20 dichromate oxidation) between filtered soil extracts of chloroform fumigated $\left(\mathrm{CHCl}_{3}, 24 \mathrm{~h}\right)$ and non-fumigated samples. Then, we used an extraction efficiency coefficient $\left(\mathrm{K}_{\mathrm{EC}}\right)$ of 0.38 (Vance et al. 1987; Joergensen 1996) to calculate microbial biomass $\mathrm{C}$ using the following equation (Eqn 2):

$$
\mathrm{MBC}=\mathrm{E}_{\mathrm{C}} / \mathrm{K}_{\mathrm{EC}}
$$

Three soil enzymatic activities corresponding to the biogeochemical cycles of C, N and P were determined. Specifically, we selected $\beta$-glucosidase (enzyme nomenclature: EC 3.2.1.21; $\beta$-D-glucoside glucohydrolase), urease (EC 3.5.1.5; 30 urea amidohydrolase) and acid phosphatase (EC 3.1.3.2; phosphate-monoester phosphohydrolase). To analyse $\beta$-glucosidase and acid phosphatase, we followed the procedure described by Tabatabai (1994), whereas urease activity was analysed according to Kandeler and Gerber (1988). For the

35 analysis of the three enzymatic activities, the soils were incubated with their corresponding enzyme substrates ( $p$-nitrophenyl- $\beta$-D-glucopyranoside, urea and $p$-nitrophenyl phosphate respectively). The products released by the enzymatic activity were determined colorimetrically with a UV-1700
PharmaSpec spectrophotometer (Shimadzu Corporation). We measured the absorbance of the $p$-nitrophenol $(p N P)$ produced by $\beta$-glucosidase and acid phosphatase activities at $400 \mathrm{~nm}$, whereas absorbance of the $\mathrm{NH}_{4}{ }^{+}$released by urease activity was measured at $690 \mathrm{~nm}$.

From the analysed soil properties, we calculated several soil quotients: (1) $\mathrm{C}: \mathrm{N}$ quotient calculated as micrograms of soil organic $\mathrm{C}$ to micrograms of total $\mathrm{N}$; (2) the microbial quotient $\left(\mathrm{Q}_{\text {mic }}\right)$ as micrograms of microbial biomass $\mathrm{C}$ to micrograms of soil organic $C$; and (3) the specific activity of soil enzymes ( $\beta$-glucosidase, urease and acid phosphatase) expressed as the micrograms of product released ( $p$ NP for $\beta$-glucosidase and acid phosphatase, and $\mathrm{NH}_{4}{ }^{+}$for urease) per micrograms of microbial biomass $\mathrm{C}$.

\section{Data analysis}

We evaluated the relationship between burn severity (explanatory variable) and each single soil property and each quotient (response variables) by fitting linear regression models (LMs). Models including single soil properties and quotients were calibrated using linear and quadratic terms to account for potential non-linear relationships, and the most parsimonious model was selected following Akaike's information criterion (AIC). The normality and homogeneity of the model residuals were checked using diagnostic plots. The goodness-of-fit of the models to the data was assessed from the coefficient of determination $\left(R^{2}\right)$ and statistical significance of the relationships $(P)$ obtained from the model summary outputs.

All data analyses were carried out with $R$ (R Core Team 2017).

\section{Results}

\section{Soil properties}

The relationships between most soil properties (MWD, $\mathrm{pH}$, organic $\mathrm{C}$, available $\mathrm{P}$, microbial biomass $\mathrm{C}$ and $\beta$-glucosidase) and field-estimated soil burn severity were quadratic (Table 2; Fig. 3). All soil properties, except total $\mathrm{N}$ and urease activity, were significantly affected by soil burn severity immediately after fire $(P<0.05)$ (Fig. 3). 
Table 2. Akaike's information criterion (AIC) values of models calculations performed between soil properties (response variables) and soil burn severity measured as the substrate stratum of the Composite Burn Index (CBI) (explanatory variable) using a linear ('CBI') and a quadratic function ('poly(CBI,2)')

The lowest AIC values for each soil property, which indicate the most adequate model, are in bold face. MWD, mean weight diameter; MBC microbial biomass $\mathrm{C}$

\begin{tabular}{llr}
\hline Soil property & CBI & AIC \\
\hline MWD & Linear & -50.226 \\
& Quadratic & $\mathbf{- 5 9 . 2 4 8}$ \\
pH & Linear & 114.122 \\
Organic C & Quadratic & $\mathbf{1 0 4 . 9 0 7}$ \\
& Linear & 382.682 \\
Total N & Quadratic & $\mathbf{3 8 1 . 9 2 4}$ \\
& Linear & $\mathbf{1 4 0 . 7 9 2}$ \\
Available P & Quadratic & 142.847 \\
& Linear & 302.148 \\
MBC & Quadratic & $\mathbf{2 9 9 . 5 0 2}$ \\
& Linear & 650.972 \\
B-Glucosidase & Quadratic & $\mathbf{6 4 9 . 4 8 0}$ \\
& Linear & 33.336 \\
Urease & Quadratic & $\mathbf{1 4 . 8 5 3}$ \\
& Linear & $\mathbf{1 2 0 . 2 2 5}$ \\
Phosphatase & Quadratic & 122.219 \\
& Linear & $\mathbf{1 2 1 . 9 4 2}$ \\
\hline
\end{tabular}

MWD showed a non-linear relationship with burn severity $\left(R^{2}=0.284 ; P<0.001\right)$ (Fig. 3), increasing at low to moderate severities $(\leq 1.75 \mathrm{CBI}$ units) and decreasing at high severities $(>2.25 \mathrm{CBI}$ units).

Soil $\mathrm{pH}$ had a strong significant relationship with burn severity (Fig. 3), and was the soil property with the highest proportion of variance explained by burn severity $\left(R^{2}=0.802\right)$. $\mathrm{pH}$ values ranged from $3-5$ in the areas burned at low severity to 7-9 in the most severely burned areas. The most pronounced

10 change in $\mathrm{pH}$ was observed at moderate and high severities (CBI $>1.25$ CBI units).

Focusing on soil major nutrients, we found a significant relationship between organic $\mathrm{C}\left(R^{2}=0.594 ; P<0.001\right)$ and available $\mathrm{P}\left(R^{2}=0.666 ; P<0.001\right)$ with burn severity (Fig. 3$)$.

15 Nevertheless, the patterns of change in both nutrients were opposed. Organic C decreased with burn severity, whereas available $\mathrm{P}$ increased with burn severity, mainly at moderate and high severities (CBI $>1.25 \mathrm{CBI}$ units). We did not find significant effects of burn severity on total $\mathrm{N}\left(R^{2}=0.059\right.$;

$20 P>0.05)$

Microbial biomass $\mathrm{C}$ showed an inverse relationship with burn severity $\left(R^{2}=0.504 ; P<0.001\right)$ (Fig. 3) following the same pattern of change as organic $C$. The highest microbial biomass $\mathrm{C}$ contents $\left(>1000 \mu \mathrm{g} \mathrm{g}^{-1}\right.$ dry soil) were obtained in 25 soils that did not burn with high severity ( $\leq 2.25 \mathrm{CBI}$ units).

Similarly, the activities of soil enzymes $\beta$-glucosidase and acid phosphatase were inversely related to burn severity. $\beta$ Glucosidase had a quadratic response to burn severity $\left(R^{2}=0.623 ; P<0.001\right)$, stronger than the linear relationship exhibited by acid phosphatase activity $\left(R^{2}=0.398 ; P<0.001\right)$. Both activities decreased from the low-severity scenario and showed values corresponding to no activity in the severely burned areas, thus being the studied soil properties most sensitive to burn severity. We did not find significant effects of burn severity on urease activity $\left(R^{2}=0.005 ; P>0.05\right)$.

\section{Soil quotients}

Several soil quotients showed significant linear $(\mathrm{C}: \mathrm{N})$ and quadratic $\left(\mathrm{Q}_{\mathrm{mic}}\right.$ and $\beta$-glucosidase:microbial biomass $\left.\mathrm{C}\right)$ inverse relationships with burn severity (Table 3; Fig. 4).

Burn severity had a significant effect on the $\mathrm{C}: \mathrm{N}$ ratio, explaining a high percentage of variance on that quotient $\left(R^{2}=0.740 ; P<0.001\right)$ (Fig. 4). The $\mathrm{C}: \mathrm{N}$ ratio strongly decreased from values of $30 \mu \mathrm{g}$ organic $\mathrm{C} \mu \mathrm{g}^{-1}$ total $\mathrm{N}$ in the lowest severities to values $\sim 5 \mu \mathrm{g}$ organic $\mathrm{C} \mu \mathrm{g}^{-1}$ total $\mathrm{N}$ in the highest severities.

The $\mathrm{Q}_{\text {mic }}$ showed a significant decrease with burn severity $\left(R^{2}=0.443 ; P<0.001\right)$ (Fig. 4). The quadratic relationship between $\mathrm{Q}_{\text {mic }}$ and burn severity suggested that changes in $\mathrm{Q}_{\mathrm{mic}}$ appeared at moderate to high severities (CBI > 1.75).

Among the specific activities of soil enzymes, only the $\beta$ glucosidase : microbial biomass $\mathrm{C}$ quotient significantly decreased with burn severity $\left(\mathrm{R}^{2}=0.497 ; P<0.001\right)$. As occurred with $\beta$-glucosidase activity, the $\beta$-glucosidase : microbial biomass $\mathrm{C}$ quotient was very sensitive to fire, showing notable decreases even at low severities with the same pattern in relation with burn severity as $\beta$-glucosidase (Figs 3,4 ).

\section{Discussion}

We developed a study to analyse fire effects on acidic soils along a burn severity gradient in a Pinus pinaster ecosystem immediately after fire (7-9 days). Our results revealed significant relationships between burn severity and physical, chemical and biological soil properties (MWD, $\mathrm{pH}$, organic $\mathrm{C}$, available $\mathrm{P}$, microbial biomass $\mathrm{C}, \beta$-glucosidase activity and acid phosphatase activity).

In the present study, we observed that the physical property MWD increased at low to moderate severities and decreased mainly at high severities. The increase in MWD may be related to the enhancement of aggregate stability that typically occurs at moderate severities in hydrophilic soils with organic matter as the main binding agent (Mataix-Solera et al. 2011). Laboratory heating experiments have clarified that aggregate stability can be enhanced at low temperatures $\left(75-200^{\circ} \mathrm{C}\right.$ ) (Santín and Doerr 2016) owing to the volatilisation of some organic matter, which then condenses on the aggregates, contributing to their stability (Mataix-Solera et al. 2011). However, at higher temperatures, stable aggregates can be dispersed (Benito et al. 2009; Varela et al. 2015; Santín and Doerr 2016) owing to major alterations in the main binding agents: the organic matter, which is depleted at high severities, and clay minerals, which are modified at extreme severities (Neary et al. 1999; Santín and Doerr 2016). The decrease in MWD at high severities involves other negative effects on ecosystems, such as loss of structure (Cerdá and Jordan 2010), and consequently a decrease in infiltration capacity and an increase in erosion rates (Vieira et al. 2015). Therefore, the burn severity impact on MWD has significant 

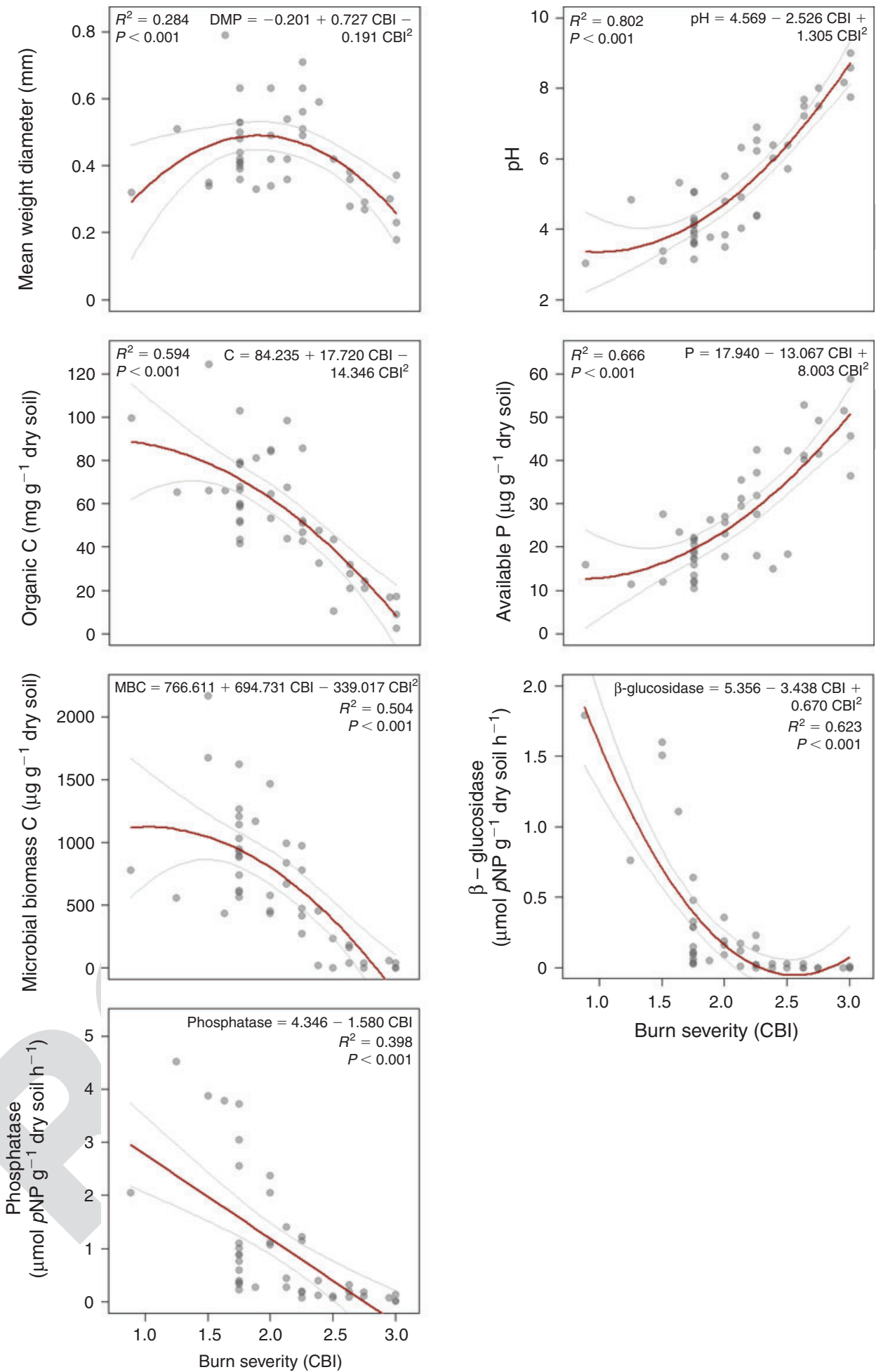

Fig. 3. Relationships between soil properties (response variables) and soil burn severity measured as the substrate stratum of the Composite Burn Index (CBI) (explanatory variable). The lines represent model-predicted values (mean $\pm 95 \%$ confidence intervals) for each soil property along the burn severity gradient. MWD = mean weight diameter; $\mathrm{MBC}=$ microbial biomass $\mathrm{C}$. 
Table 3. Akaike's information criterion (AIC) values of models calculations performed between soil quotients (response variables) and soil burn severity measured as the substrate stratum of the Composite Burn Index (CBI) (explanatory variable) using a linear ('CBI') and a quadratic function ('poly(CBI, 2)')

The lowest AIC values for each soil property, which indicate the most adequate model, are in bold face. $\mathrm{Q}_{\mathrm{mic}}$, microbial quotient; $\mathrm{MBC}$, microbial biomass $\mathrm{C}$

\begin{tabular}{llr}
\hline Soil quotient & CBI & \multicolumn{1}{c}{ AIC } \\
\hline C:N & Linear & $\mathbf{2 4 6 . 7 7 3}$ \\
& Quadratic & 247.696 \\
Qmic & Linear & 76.414 \\
$\beta$-Glucosidase : MBC & Quadratic & $\mathbf{7 1 . 9 9 7}$ \\
& Linear & -101.162 \\
Urease : MBC & Quadratic & $\mathbf{- 1 1 1 . 8 2 8}$ \\
& Linear & $\mathbf{4 7 . 6 9 4}$ \\
Phosphatase : MBC & Quadratic & 49.612 \\
& Linear & $\mathbf{5 2 . 2 8 1}$ \\
& Quadratic & 54.105 \\
\hline
\end{tabular}

ecological consequences, especially in areas where the potential erosion risk is very high, such as southern Europe (Van der Knijff et al. 2000).

The soil chemical properties $\mathrm{pH}$, soil organic $\mathrm{C}$ and available $\mathrm{P}$ were also affected by burn severity immediately (7-9 days) after fire. We found proportional decreases in organic $\mathrm{C}$ concentration at moderate and high severity, our results being consistent with those found in previous research on fire ecology (Vega et al. 2013). Loss of organic $\mathrm{C}$ in the mineral soil starts at

10 moderate severities (Key and Benson 2006; Keeley 2009) and is a consequence of organic matter mineralisation and volatilisation caused by fire (Caon et al. 2014). Laboratory heating experiments indicated that organic $\mathrm{C}$ concentration in Mediterranean $P$. pinaster ecosystems with acidic soils decreases at

15 temperatures higher than $220^{\circ} \mathrm{C}$ (Varela et al. 2015). The opposite trend was found for $\mathrm{pH}$ and available $\mathrm{P}$. $\mathrm{pH}$ showed a large increase (almost $6 \mathrm{pH}$ units) with burn severity, exceeding figures reported in other field studies (Certini 2005; Marcos et al. 2007; Vega et al. 2013) and is similar to increases found in

20 acidic soils from $P$. pinaster ecosystems heated to $800^{\circ} \mathrm{C}$ under laboratory conditions (Fuertes 2015), suggesting that temperatures reached in the study site were fairly high. Increases in $\mathrm{pH}$ are due to denaturation of organic acids and the release of bases from organic matter mineralisation (Neary et al. 2008; Alcañiz

25 et al. 2018). Similarly, the mineralisation of organic matter converts organic P into available P (Certini 2005; Marcos et al. 2007), which is frequently limiting in forest soils (Neary et al. 2008), especially in those developed from highly siliceous lithologies (Binkler and Fisher 2013), which is the case in our

30 study area. Additionally, burn severity may have a significant effect on the concentration of available $\mathrm{P}$ in acidic soils through the increase in $\mathrm{pH}$, as maximum $\mathrm{P}$ availability is between $\mathrm{pH} 6$ and 7.5 (Neary et al. 2008). Therefore, changes caused by burn severity in both soil properties, $\mathrm{pH}$ and available $\mathrm{P}$ content, are

35 particularly relevant in acidic soils in $P$. pinaster ecosystems, because they have notable implications in soil fertility. In this study, we did not find significant effects of burn severity on total
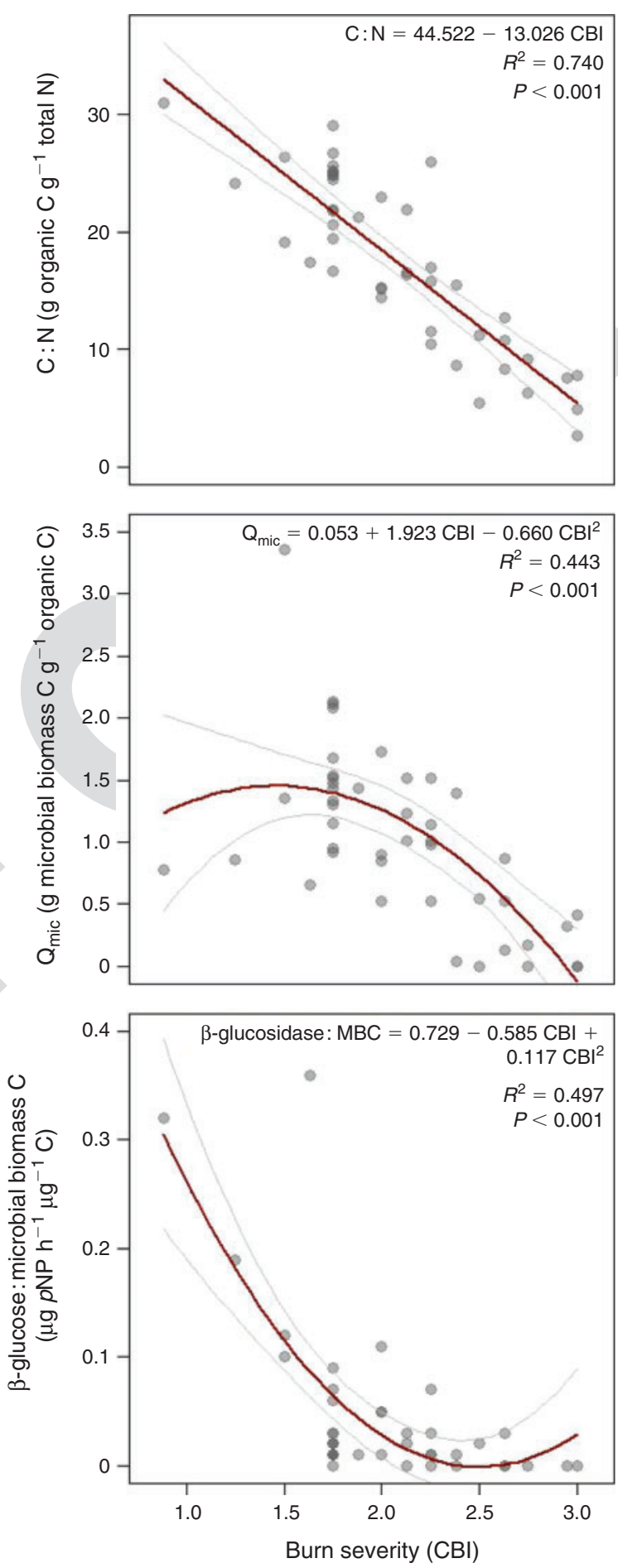

Fig. 4. Relationships between soil quotients (response variables) and soil burn severity measured as the substrate stratum of the Composite Burn Index (CBI) (explanatory variable). The lines represent model-predicted values (mean $\pm 95 \%$ confidence intervals) for each soil property along the burn severity gradient. $\mathrm{MBC}=$ microbial biomass $\mathrm{C}$.

$\mathrm{N}$ concentration, which can be attributed to low $\mathrm{N}$ losses by volatilisation (Caon et al. 2014). Other studies have not found changes in total $\mathrm{N}$ in Mediterranean soils after fire (Caon et al. 
2014), or in soils heated in laboratory at $350^{\circ} \mathrm{C}$ for $1 \mathrm{~h}$ (Tecimen and Sevgi 2011).

The biological soil properties significantly affected by burn severity (microbial biomass $\mathrm{C}, \beta$-glucosidase activity and acid phosphatase activity) strongly decreased (to zero) in the highestseverity scenario. Declines in microbial biomass $\mathrm{C}$ with burn severity were found by Vega et al. (2013) in P. pinaster ecosystems. The decrease in microbial biomass $\mathrm{C}$ is attributed to the mortality of microorganisms occurring between 50 and

$10160^{\circ} \mathrm{C}$ (Neary et al. 2008; Vega et al. 2013). Additionally, changes caused by fire in soil nutrients, moisture and temperature may affect the abundance of microorganisms (Dooley and Treseder 2012). Similarly, temperatures above $60-70^{\circ} \mathrm{C}$ bring about the inactivation and denaturation of soil enzymes

15 (Tabatabai 1994). These temperatures are lower than necessary to produce significant effects on the other soil properties analysed in the present study (Neary et al. 2008). Therefore, the soil enzymes $\beta$-glucosidase and acid phosphatase are the soil properties most sensitive to burn severity in the present study,

20 understood to be the first properties affected, decreasing from severities of $\sim 1.25 \mathrm{CBI}$ units (considered the severity threshold between visible changes and no visible changes in the mineral soil; see Table 1; Key and Benson 2006) to 2.5 CBI units, where no activity was found. In contrast, we did not find significant

25 effects of burn severity on urease activity. We hypothesise that the high $\mathrm{NH}_{4}{ }^{+}$concentration, which is expected in soils immediately after fire (Certini 2005; Caon et al. 2014), may inhibit the enzyme reaction (Goberna et al. 2012), as well as mask the enzyme activity determination, as it is quantified by the $\mathrm{NH}_{4}{ }^{+}$ 30 released (Kandeler and Gerber 1988).

Among the soil quotients, we found a significant relationship between burn severity and the $\mathrm{C}: \mathrm{N}$ ratio, $\mathrm{Q}_{\mathrm{mic}}$ and $\beta$-glucosidase : microbial biomass $\mathrm{C}$ quotient. The decrease in $\mathrm{C}: \mathrm{N}$ ratio with fire (González-Pérez et al. 2004; Santín et al. 2008) and,

35 particularly, the inverse relationship between $\mathrm{C}: \mathrm{N}$ ratio and burn severity have been noted in previous studies (Vega et al. 2013). Thus, burn severity can transform oligotrophic soils into eutrophic soils (from C:N>20 to <12; Porta et al. 1999), conditioning the composition of the future plant community (Pöyry et al.

40 2017). This result can be attributed to higher losses caused by fire in soil organic $\mathrm{C}$ than in $\mathrm{N}$, which is volatilised at higher temperatures (Neary et al. 2008), and to the increase in recalcitrant organic $\mathrm{N}$ forms in charred remains (Santín et al. 2008). Apart from the sensitivity to fire, the quite constant values of the

$45 \mathrm{C}: \mathrm{N}$ ratio among undisturbed forest soils (Wild 1992) suggest that this quotient may be a generalisable tool to analyse fire impact on soils. Similarly, we found decreases in $\mathrm{Q}_{\text {mic }}$ with burn severity, which can be attributed to a higher impact on microbial biomass C than on organic C (Bastida et al. 2008). Several 50 authors have noted that $\mathrm{Q}_{\text {mic }}$ values of 2.2 reflect a good equilibrium between both $\mathrm{C}$ fractions (Bastida et al. 2008), whereas $\mathrm{Q}_{\text {mic }}$ values lower than 2 are indicative of organic matter depletion (Lagomarsino et al. 2009; Paz-Ferreiro and Fu 2016). This suggests a large decrease in organic matter in the highest-

55 severity scenarios ( $>2.5 \mathrm{CBI}$ units) of our study, where $\mathrm{Q}_{\text {mic }}$ values were always lower than 1. Among the specific activities of soil enzymes, $\beta$-glucosidase : microbial biomass $C$ decreased with burn severity. Studies carried out by Lagomarsino et al. (2009) in agrarian ecosystems have pointed out the $\beta$-glucosidase : microbial biomass ratio as the most sensitive specific enzyme activity to indicate land-use impacts. The inverse relationship between this ratio and burn severity could be explained by (1) a decrease in $\beta$-glucosidase activity per microbial biomass unit (Waldrop et al. 2000); (2) $\beta$-glucosidase immobilisation in clays or humic colloids; and (3) a decrease in the concentration of glucopyranosides (Bastida et al. 2008).

The present study contributes to advancing knowledge of what soil burn severity means for the soil status and functioning immediately after fire in $P$. pinaster ecosystems with acidic soils. Additionally, our results revealed several soil properties that could be considered key for monitoring fire impacts on soils, owing to their high sensitivity to burn severity and their relationship with relevant soil ecological processes. Among them, (1) $\mathrm{pH}$ showed the strongest relationship with burn severity, with a large increase at moderate and high severities; (2) the activity of soil enzymes acid phosphatase and particularly $\beta$-glucosidase (both the single soil property and the soil quotient as specific enzyme activity) showed the highest sensitivity to fire, decreasing from the low-severity scenario; and (3) the $\mathrm{C}: \mathrm{N}$ quotient, whose results could be more generalisable, showing a progressive decrease with burn severity. However, it has been recognised that not all changes caused by fire in soil properties persist for a long time, depending on the magnitude of the fire impact and the recovery of vegetation, among other factors (Certini 2005; Alcañiz et al. 2016; Muñoz-Rojas et al. 2016). Therefore, we recommend monitoring the evolution of soil properties in relation to burn severity over the medium and long term after a wildfire in fire-prone pine ecosystems.

Research on how burn severity affects soil properties is particularly relevant in the European countries of the Mediterranean Basin, because land-use changes occurring during recent decades have led to an increase in fuel amount and continuity (Pausas et al. 2008; Doblas-Miranda et al. 2017), thus constituting landscapes prone to large high-severity fires (San-Miguel-Ayanz et al. 2016; García-Llamas et al. 2019). This new fire-regime pattern could be enhanced in the current context of climate change owing to climate-driven increases in burn severity and the area affected by fire because of the drier and warmer climate expected in many regions of the world (Azpeleta et al. 2014; San-Miguel-Ayanz et al. 2016). Consequently, the present study not only contributes to a better understanding of changes occurring in a particular situation, but can also inform on fire impacts in $P$. pinaster forests under in future scenarios of increasing burn severity.

\section{Conclusions}

This study adds to the knowledge on how field-estimated burn severity is related to changes in single soil properties (physical, chemical and biological) as well as in soil quotients indicative of soil status and processes in Pinus pinaster ecosystems with acidic soils immediately (7-9 days) after fire. Specifically, our results showed that decreases in the size of stable aggregates (MWD) occurred mainly at high burn severities, whereas changes in chemical properties ( $\mathrm{pH}$, organic $\mathrm{C}$ and available $\mathrm{P}$ ) were associated with moderate and high severities. We also demonstrated that biological properties, and particularly the activity of soil enzymes ( $\beta$-glucosidase and acid phosphatase) are one of the 
most sensitive properties to burn severity as they largely decrease from the low-severity scenarios, becoming depleted at the highest severities. Furthermore, burn severity affected the $\mathrm{C}: \mathrm{N}$ ratio, microbial quotient and the specific activity of $\beta$-glucosidase. In view of our results, we propose $\mathrm{pH}, \beta$-glucosidase activity and $\mathrm{C}: \mathrm{N}$ ratio as key properties in surveying fire impacts on soils immediately after fire in $P$. pinaster ecosystems, because of their sensitivity and potential generalisation.

This research constitutes a benchmark for monitoring longer-

10 term relationships between burn severity and soil properties in $P$. pinaster ecosystems, as well as forecasting the effects of fire in the future, considering the predictions of more severe wildfires in the Mediterranean region.

\section{Conflicts of interest}

15 The authors declare that they have no conflicts of interest.

\section{Declaration of funding}

This study was financially supported by the Spanish Ministry of Economy and Competitiveness, and the European Regional Development Fund (ERDF), in the framework of the GESFIRE

20 (AGL2013-48189-C2-1-R) and FIRESEVES (AGL2017$86075-\mathrm{C} 2-1-\mathrm{R})$ projects, and by the Regional Government of Castile and León in the framework of the FIRECYL (LE033U14) and SEFIRECYL (LE001P17) projects. Víctor Fernández-García and José Manuel Fernández-Guisuraga were supported by pre-

25 doctoral fellowships from the Spanish Ministry of Education (FPU14/00636 and FPU16/03070).

\section{Acknowledgements}

We thank the anonymous reviewers for their comments, which contributed 30 to improving the quality of the manuscript.

\section{References}

Adetunji AT, Lewu FB, Mulidzi R, Ncube B (2017) The biological activities of $\beta$-glucosidase, phosphatase and urease as soil quality indicators: a review. Journal of Soil Science and Plant Nutrition 17, 794-807. doi:10.4067/S0718-95162017000300018

Agencia Estatal de Meteorología, Instituto de Meteorologia de Portugal (Eds) (2011) 'Iberian climate atlas. Air temperature and precipitation (1971-2000).' (Agencia Estatal de Meteorología, Ministerio de Medio Ambiente y Medio Rural y Marino. Instituto de Meteorologia de Portugal: Paracuellos del Jarama, Spain)

Alcañiz M, Outeiro L, Francos M, Farguell J, Úbeda X (2016) Long-term dynamics of soil chemical properties after a prescribed fire in a Mediterranean forest (Montgrí Massif, Catalonia, Spain). The Science of the Total Environment 572, 1329-1335. doi:10.1016/J.SCITOTENV. 2016.01 .115

Alcañiz M, Outeiro L, Francos M, Úbeda X (2018) Effects of prescribed fires on soil properties: a review. The Science of the Total Environment 613-614, 944-957. doi:10.1016/J.SCITOTENV.2017.09.144

Área de Defensa contra Incendios Forestales del Ministerio de Agricultura,

50 Alimentación y Medio Ambiente (2012) Los incendios forestales en España. Decenio 2001-2010. Área de Defensa contra Incendios Forestales del Ministerio de Agricultura, Alimentación y Medio Ambiente. Available at https:/www.mapa.gob.es/es/desarrollo-rural/estadisticas/ [Verified 1 November 2018]

55 Arshad MA, Martin S (2002) Identifying critical limits for soil quality indicators in agro-ecosystems. Agriculture, Ecosystems \& Environment 88, 153-160. doi:10.1016/S0167-8809(01)00252-3
Azpeleta A, Fulé PZ, Shive KL, Sieg CH, Sanchez Meador A, Strom B (2014) Simulating post-wildfire forest trajectories under alternative climate and management scenarios. Ecological Applications 24, 16261637. doi:10.1890/13-1787.1

Badía D, Martí C, Aguirre AJ, Aznar JM, González-Pérez JA, De la Rosa JM, León J, Ibarra P, Echeverría T (2014) Wildfire effects on nutrients and organic carbon of a Rendzic Phaeozem in NE Spain: changes at cm-scale topsoil. Catena 113, 267-275. doi:10.1016/J.CATENA.2013.08.002

Bastida F, Zsolnay A, Hernández T, García C (2008) Past, present and future of soil quality indices: a biological perspective. Geoderma 147, 159-171. doi:10.1016/J.GEODERMA.2008.08.007

Benito E, Soto B, Varela E, Rodríguez Alleres M, Rodríguez Suárez JA (2009) Modificaciones inducidas por los incendios forestales en las propiedades físicas de los suelos del noroeste de España: implicaciones en la respuesta hidrológica y en la erosión hídrica. In 'Efectos de los incendios forestales sobre los suelos de España'. (Eds A Cerdá, J MataixSolera) pp. 305-323. (FUEGORED, Cátedra de Divulgació de la Ciència, Universitat de València: Valencia, Spain).

Binkler D, Fisher R (Eds) (2013) 'Ecology and management of forest soils.' (Wiley-Blackwell: Chichester, UK)

Bremner JM, Mulvaney CS (1982) Nitrogen total. In 'Methods of soil analysis Part 2: Chemical and microbiological properties'. (Eds AL Page, RH Miller, DR Keeney) pp. 595-624. (American Society of Agronomy (ASA): Madison, WI, USA)

Caon L, Vallejo VR, Ritsema CJ, Geissen V (2014) Effects of wildfire on soil nutrients in Mediterranean ecosystems. Earth-Science Reviews 139 47-58. doi:10.1016/J.EARSCIREV.2014.09.001

Cerdà A, Jordan A (Eds) (2010) 'Actualización en métodos y técnicas para el estudio de los suelos afectados por los incendios forestales.' (Càtedra de Divulgaciò de la Ciència, Universitat de València, FUEGORED : Valencia, Spain).

Certini G (2005) Effects of fire on properties of forest soils: a review Oecologia 143, 1-10. doi:10.1007/S00442-004-1788-8

Doblas-Miranda E, Alonso R, Arnan X, Bermejo V, Brotons L, de las Heras J, Estiarte M, Hódar JA, Llorens P, Lloret F, López-Serrano FR, Martínez-Vilalta J, Moya D, Peñuelas J, Pino J, Rodrigo A, RouraPascual N, Valladares F, Vilà M, Zamora R, Retana J (2017) A review of the combination among global change factors in forests, shrublands and pastures of the Mediterranean region: beyond drought effects Global and Planetary Change 148, 42-54. doi:10.1016/J.GLOPLA CHA.2016.11.012

Dooley S, Treseder KK (2012) The effect of fire on microbial biomass: a meta-analysis of field studies. Biogeochemistry 109, 49-61. doi:10. 1007/S10533-011-9633-8

Dzwonko Z, Loster S, Gawronski S (2015) Impact of fire severity on soil properties and the development of tree and shrub species in a Scots pine moist forest site in southern Poland. Forest Ecology and Management 342, 56-63. doi:10.1016/J.FORECO.2015.01.013

Fernández-García V, Santamarta M, Fernández-Manso A, Quintano C, Marcos E, Calvo L (2018a) Burn severity metrics in fire-prone pine ecosystems along a climatic gradient using Landsat imagery. Remote Sensing of Environment 206, 205-217. doi:10.1016/J.RSE.2017.12.029

Fernández-García V, Quintano C, Taboada A, Marcos E, Calvo L, Fernández-Manso A (2018b) Remote sensing applied to the study of fire regime attributes and their influence on post-fire greenness recovery in pine ecosystems. Remote Sensing 10, 733. doi:10.3390/RS10050733

Fuertes A (2015) Soil characteristics as severity indicators after fire in a Pinus pinaster pinewood. Final year dissertation. Universidad de León, León, Spain.

García-Llamas P, Suárez-Seoane S, Taboada A, Fernández-Manso A, Quintano C, Fernández-García V, Fernández-Guisuraga JM, Marcos E, Calvo L (2019) Environmental drivers of fire severity in extreme fire events that affect Mediterranean pine forest ecosystems. Forest Ecology and Management 433, 24-32. doi:10.1016/J.FORECO.2018.10.051 
GEODE (2018) Mapa continuo digital de España. Instituto Geológico y Minero de España. Available at http://mapas.igme.es/gis/services/Cartografia_Geologica/IGME_Geode_50/MapServer/WMSServer [Verified 20 May 2018]

Gil-Sotres F, Trasar-Cepeda C, Leirós MC, Seoane S (2005) Different approaches to evaluating soil quality using biochemical properties. Soil Biology \& Biochemistry 37, 877-887. doi:10.1016/J.SOILBIO. 2004.10.003

Goberna M, García C, Insam H, Hernández MT, Verdú M (2012) Burning

10 fire-prone Mediterranean shrublands: immediate changes in soil microbial community structure and ecosystem functions. Microb Ecol 64, 242-255. doi:10.1007/S00248-011-9995-4.

González-Pérez JA, González-Vila FJ, Almendros G, Knicker H (2004) The effect of fire on soil organic matter - a review. Environment International 30, 855-870. doi:10.1016/J.ENVINT.2004.02.003

Instituto da Conservação da Natureza e das Florestas (2015) Áreas ardidas por tipo de ocupação do solo (1996-2014). Available at http://www2.icnf.pt/ portal/florestas/dfci/inc/estat-sgif\#tip [Verified 1 November 2018]

Jain TB, Pilliod DS, Graham RT, Lentile LB, Sandquist JE (2012) Index

20 for characterizing post-fire soil environments in temperate coniferous forests. Forests 3, 445-466. doi:10.3390/F3030445

Joergensen JG (1996) The fumigation-extraction method to estimate soil microbial biomass: calibration of the $k_{\mathrm{EC}}$ value. Soil Biology \& Biochemistry 28, 25-31. doi:10.1016/0038-0717(95)00102-6

25 Jones A, Montanarella L, Jones R (2005) 'Soil atlas of Europe.' (European Commission: Luxembourg).

Jordán A, Zavala LM, Mataix-Solera J, Nava AL, Alanís N (2011) Effect of fire severity on water repellency and aggregate stability on Mexican volcanic soils. Catena 84, 136-147. doi:10.1016/J.CATENA.2010. 10.007

Kandeler E, Gerber H (1988) Short-term assay of soil urease activity using colorimetric determination of ammonium. Biology and Fertility of Soils 6, 68-72. doi:10.1007/BF00257924

Keeley JE (2009) Fire intensity, fire severity and burn severity: a brief

35 review and suggested usage. International Journal of Wildland Fire 18, 116-126. doi:10.1071/WF07049

Keeley JE, Bond WJ, Bradstock RA, Pausas J, Rundel PW (Eds) (2012) 'Fire in Mediterranean ecosystems. Ecology, evolution and management.' (Cambridge University Press: Cambridge, UK).

40 Kemper WD, Rosenau RC (1986) Aggregate stability and size distribution. In 'Methods of soil analysis Part 1: Physical and mineralogical methods'. (Ed. A Klute) pp. 415-442. (ASA: Madison, WI, USA).

Key CH, Benson NC (2006) Landscape assessment (LA) sampling and analysis methods. USDA Forest Service, Rocky Mountain Research

45 Station, General Technical Report, RMRS-GTR-164-CD. (Fort Collins, CO, USA)

Lagomarsino A, Moscatelli MC, Tizio AD, Mancinelli R, Grego S, Marinari S (2009) Soil biochemical indicators as a tool to assess the short-term impact of agricultural management on changes in organic $\mathrm{C}$ in a Mediterranean environment. Ecological Indicators 9, 518-527. doi:10.1016/J.ECOLIND.2008.07.003

Li Y-T, Rouland C, Benedetti M, Li F-B, Pando A, Lavelle P, Dai J (2009) Microbial biomass, enzyme and mineralization activity in relation to soil organic C, N and P turnover influenced by acid metal stress. Soil Biology \& Biochemistry 41, 969-977. doi:10.1016/J.SOILBIO.2009.01.021

Lindner M, Garcia-Gonzalo J, Kolström M, Geen T, Reguera R, Maroschek M, Seidl R, Lexer MJ, Netherer S, Schopf A, Kremer A, Delzon S, Barbati A, Marchetti M, Corona P (2008) Impacts of climate change on European forests and options for adaptation. Report (AGRI-2007-G406) to the European Commission Directorate-General for Agriculture and Rural Development. Available at https:/ec.europa.eu/agriculture/ external-studies/euro-forests_en [Verified 1 November 2018]

Marcos E, Tárrega R, Luis E (2007) Changes in a Humic Cambisol heated $\left(100-500^{\circ} \mathrm{C}\right)$ under laboratory conditions: the significance of heating time. Geoderma 138, 237-243. doi:10.1016/J.GEODERMA.2006. 11.017

Mataix-Solera J, Cerdà A, Arcenegui V, Jordán A, Zavala LM (2011) Fire effects on soil aggregation: a review. Earth-Science Reviews 109, 44-60. doi:10.1016/J.EARSCIREV.2011.08.002

Merino A, Fonturbel MT, Fernández C, Chávez-Vergara B, García-Oliva F, Vega JA (2018) Inferring changes in soil organic matter in postwildfire soil burn severity levels in a temperate climate. The Science of the Total Environment 627, 622-632. doi:10.1016/J.SCITOTENV. 2018.01.189

Miesel JR, Hockaday WC, Kolka RK, Townsend PA (2015) Soil organic matter composition and quality across fire severity gradients in coniferous and deciduous forests of the southern boreal region. Journal of Geophysical Research. Biogeosciences 120, 1124-1141. doi:10.1002/ 2015JG002959

Moody JA, Ebel BA, Nyman P, Martin DA, Stoof CR, McKinley R (2016) Relations between soil hydraulic properties and burn severity. International Journal of Wildland Fire 25, 279-293. doi:10.1071/WF14062

Moreira F, Viedma O, Arianoutsou M, Curt T, Koutsias N, Rigolot E, Barbati A, Corona P, Vaz P, Xanthopoulos G, Mouillot L, Bilgiri E (2011) Landscape-wildfire interactions in southern Europe: implications for landscape management. Journal of Environmental Management 92, 2389-2402. doi:10.1016/J.JENVMAN.2011.06.028

Moreira F, Arianoutsou M, Corona P, De las Heras J (Eds) (2012) 'Post-fire management and restoration of southern European forests.' (Springer Science+Business Media BV: Dordrecht, Netherlands)

Muñoz-Rojas M, Erickson TE, Martini D, Dixon KW, Merritt D (2016) Soil physicochemical and microbiological indicators of short-, mediumand long-term post-fire recovery in semi-arid ecosystems. Ecological Indicators 63, 14-22. doi:10.1016/J.ECOLIND.2015.11.038

National Oceanic and Atmospheric Administration (2018) Global surface summary of the day - GSOD. National Climatic Data Center, NESDIS, National Oceanic and Atmospheric Administration, US Department of Commerce. Available at https://data.nodc.noaa.gov/cgi-bin/iso?id=gov. noaa.ncdc:C00516ICNF [Verified 1 November 2018]

Neary DG, Klopatek CC, DeBano LF, Ffolliott PF (1999) Fire effects on belowground sustainability: a review and synthesis. Forest Ecology and Management 122, 51-71. doi:10.1016/S0378-1127(99)00032-8

Neary DG, Ryan KC, DeBano LF (2008) Wildland fire in ecosystems: effects of fire on soils and water. USDA Forest Service, Rocky Mountain Research Station, General Technical Report RMRS-GTR-42-Vol. 4. (Ogden, UT, USA).

Nelson DW, Sommers LE (1982) Total carbon, organic carbon and organic matter. In 'Methods of soil analysis Part 2: Chemical and microbiological properties'. (Eds AL Page, RH Miller, DR Keeney) pp. 539-579. (ASA: Madison, WI, USA).

Ninyerola M, Pons X, Roure JM (Eds) (2005) 'Atlas climático digital de la Península Ibérica. Metodología y aplicaciones en bioclimatología y geobotánica.' (Universidad Autónoma de Barcelona: Bellaterra, Spain)

Noss RF, Franklin JF, Baker WL, Schoennagel PM, Moyle PB (2006) Managing fire-prone forests in the western United States. Frontiers in Ecology and the Environment 4, 481-487. doi:10.1890/1540-9295 (2006)4[481:MFFITW]2.0.CO;2

Olsen SR, Cole CV, Frank SW, Dean LA (1954) Estimation of available phosphorus in soils by extraction with sodium bicarbonate. USDA Circular No. 939. US Government Printing Office. (Washington DC, USA)

Parsons A, Robichaud PR, Lewis SA, Napper C, Clark J, Jain T (2010) Field guide for mapping post-fire soil burn severity. USDA Forest Service, Rocky Mountain Research Station, General Technical Report RMRSGTR-243. (Fort Collins, CO, USA)

Pausas JG, Llovet J, Rodrigo A, Vallejo R (2008) Are wildfires a disaster in the Mediterranean basin? A review. International Journal of Wildland Fire 17, 713-723. doi:10.1071/WF07151 
Paz-Ferreiro J, Fu S (2016) Biological indices for soil quality evaluation: perspectives and limitations. Land Degradation \& Development 27, 14 25. doi:10.1002/LDR.2262

Piao HC, Liu GS, Wu YY, Xu WB (2001) Relationships of soil microbial biomass carbon and organic carbon with environmental parameters in mountainous soils of south-west China. Biology and Fertility of Soils $\mathbf{3 3}$, 347-350. doi:10.1007/S003740000328

Pingree MRA, Homann PS, Morrissette B, Darbyshire R (2012) Long- and short-term effects of fire on soil charcoal of a conifer forest in south-west Oregon. Forests 3, 353-369. doi:10.3390/F3020353

Porta J, López-Acevedo M, Roquero C (Eds) (1999) 'Edafología para la agricultura y el medio ambiente.' (Ediciones Mundi-Prensa: Madrid, Spain).

Pöyry J, Carvalheiro LG, Heikkinen RK, Kühn I, Kuussaari M, Schweiger O, Valtonen A, van Bodegom PM, Franzén M (2017) The effects of soil eutrophication propagate to higher trophic levels. Global Ecology and Biogeography 26, 18-30. doi:10.1111/GEB.12521

Puglisi E, Del Re AMM, Rao MA, Gianfreda L (2006) Development and validation of numerical indexes integrating enzyme activities of soils. Soil Biology \& Biochemistry 38, 1673-1681. doi:10.1016/J.SOILBIO 2005.11.021

R Core Team (2017) R: A language and environment for statistical computing. R Foundation for Statistical Computing. (Vienna, Austria). Available at http://www.R-project.org/ [Verified 1 November 2018]

25 Roem WJ, Berendse F (2000) Soil acidity and nutrient supply ratio as possible factors determining changes in plant species diversity in grassland and heathland communities. Biological Conservation 92 151-161. doi:10.1016/S0006-3207(99)00049-X

San-Miguel-Ayanz J, Durrant T, Boca R, Libertà G, Bocacci F, Di Leo M, López-Pérez J, Schulte E (2016) Forest fires in Europe, Middle East and North Africa 2015. Joint Research Centre of the European Commission Technical Reports, EUR 28158 EN. Available at http://dx.doi.org/ 10.2788/914 [Verified 1 November 2018]

Santín C, Doerr S (2016) Fire effects on soils: the human dimension. 35 Philosophical Transactions of the Royal Society of London. Series B. Biological Sciences 371, 20150171. doi:10.1098/RSTB.2015.0171

Santín C, Knicker H, Fernández S, Menéndez-Duarte R, Álvarez MA (2008) Wildfires influence on soil organic matter in an Atlantic mountainous region (NW of Spain). Catena 74, 286-295. doi:10.1016/J
Schnecker J, Wild B, Takriti M, Eloy Alves RJ, Gentsch N, Gittel A, Hofer A, Klaus K, Knoltsch A, Lashchinskiy N, Mikutta R, Richter A (2015) Microbial community composition shapes enzyme patterns in topsoil and subsoil horizons along a latitudinal transect in western Siberia. Soil Biology \& Biochemistry 83, 106-115. doi:10.1016/J.SOILBIO. 2015.01.016

Shakesby RA (2011) Post-wildfire soil erosion in the Mediterranean: review and future research directions. Earth-Science Reviews 105, 71-100. doi:10.1016/J.EARSCIREV.2011.01.001

Tabatabai MA (1994) Soil enzymes. In 'Methods of soil analysis. Part 2: Microbial and biochemical properties'. (Eds RW Weaver, JS Angle, PJ Bottomley, DF Bezdicek, S Smith, MA Tabatabai, AG Wollum) pp. 539-579. (ASA: Madison, WI, USA).

Tecimen HB, Sevgi O (2011) Heating-induced changes in mineral nitrogen and organic carbon in relation with temperature and time. Journal of Environmental Biology 32, 295-300.

Van der Knijff JM, Jones RJA, Montanarella L (2000) Soil erosion risk assessment in Europe. Joint Research Centre of the European Commission Report, EUR 19044 EN. Available at https://esdac.jrc.ec.europa.eu/content/soil-erosion-risk-assessment-europe [Verified 1 November 2018]

Vance ED, Brookes PC, Jenkinson DS (1987) An extraction method for measuring soil microbial biomass C. Soil Biology \& Biochemistry 19 703-707. doi:10.1016/0038-0717(87)90052-6

Varela ME, Benito E, Keizer JJ (2015) Influence of wildfire severity on soil physical degradation in two pine forest stands of NW Spain. Catena 133, 342-348. doi:10.1016/J.CATENA.2015.06.004

Vega JA, Fontúrbel T, Merino A, Fernández C, Ferreiro A, Jiménez E (2013) Testing the ability of visual indicators of soil burn severity to reflect changes in soil chemical and microbial properties in pine forests and shrubland. Plant and Soil 369, 73-91. doi:10.1007/S11104-012$1532-9$

Vieira DCS, Fernández C, Vega JA, Keizer JJ (2015) Does soil burn severity affect the post-fire runoff and interrill erosion response? A review based on meta-analysis of field rainfall simulation data. Journal of Hydrology 523, 452-464. doi:10.1016/J.JHYDROL.2015.01.071

Waldrop MP, Balser TC, Firestone MK (2000) Linking microbial community composition to function in a tropical soil. Soil Biology \& Biochemistry 32, 1837-1846. doi:10.1016/S0038-0717(00)00157-7

Wild A (1992) 'Condiciones del suelo y desarrollo de las plantas según Russell.’ (Ediciones Mundi-Prensa: Madrid, Spain). 